BNL Citric Acid Technology: Pilot Scale Demonstration

A.J. Francis, C. J. DoDGE AND J. B. GLLLow
Department of Applied Science, Brookhaven National Laboratory, Upton, NY 11973
and
Kerth E. FORRESTER, Forrester Environmental Services Inc. [FESI]
Hampton, New Hampshire 03843-2008
RECEIVED
ABSTRACT
JAN 032000

The objective of this project is to remove toxic metals such as lead and cadmium from incinerator ash using the Citric Acid Process developed at Brookhaven National Laboratory. In this process toxic metals in bottom ash from the incineration of municipal solid waste were first extracted with citric acid followed by biodegradation of the citric acid-metal extract by the bacterium Pseudomonas fluorescens for metals recovery. The ash contained the following metals: $\mathrm{Al}, \mathrm{As}, \mathrm{Ba}, \mathrm{Ca}, \mathrm{Cd}, \mathrm{Cr}, \mathrm{Cu}, \mathrm{Fe}, \mathrm{Mg}, \mathrm{Mn}, \mathrm{Ni}, \mathrm{Pb}, \mathrm{Se}, \mathrm{Sr}, \mathrm{Ti}$, and $\mathrm{Zn}$. Optimization of the Citric Acid Process parameters which included citric acid molarity, contact time, the impact of mixing aggressiveness during extraction and pretreatment showed lead and cadmium removal from incinerator ash of $>90 \%$. Seeding the treated ash with $P$. fluorescens resulted in the removal of residual citric acid and biostabilization of any leachable lead, thus allowing it to pass EPA's Toxicity Characteristic Leaching Procedure. Biodegradation of the citric acid extract removed $>99 \%$ of the lead from the extract as well as other metals such as $\mathrm{Al}, \mathrm{Ca}, \mathrm{Cu}, \mathrm{Fe}, \mathrm{Mg}$, $\mathrm{Mn}, \mathrm{Ti}$, and $\mathrm{Zn}$. Speciation of the bioprecipitated lead by Extended X-ray Absorption Fine Structure at the National Synchrotron Light Source showed that the lead is predominantly associated with the phosphate and carboxyl functional groups in a stable form. Citric acid was completely recovered ( $>99 \%)$ from the extract by sulfide precipitation technique and the extraction efficiency of recovered citric acid is similar to that of the fresh citric acid. Recycling of the citric acid should result in considerable savings in the overall treatment cost. We have shown the potential application of this technology to remove and recover the metal contaminants from incinerator ash as well as from other heavy metal bearing wastes (i.e., electric arc furnace dust from steel industry) or soils. Information developed from this project is being applied to demonstrate the remediation of lead paint contaminated soils on Long Island. 


\section{DISCLAIMER}

This report was prepared as an account of work sponsored by an agency of the United States Government. Neither the United States Government nor any agency thereof, nor any of their employees, make any warranty, express or implied, or assumes any legal liability or responsibility for the accuracy, completeness, or usefulness of any information, apparatus, product, or process disclosed, or represents that its use would not infringe privately owned rights. Reference herein to any specific commercial product, process, or service by trade name, trademark, manufacturer, or otherwise does not necessarily constitute or imply its endorsement, recommendation, or favoring by the United States Government or any agency thereof. The views and opinions of authors expressed herein do not necessarily state or reflect those of the United States Government or any agency thereof. 


\section{DISCLAIMER}

Portions of this document may be illegible in electronic image products. Images are produced from the best available original document. 


\title{
BNL CITRIC ACID TECHNOLOGY: PILOT SCALE DEMONSTRATION
}

\author{
A. J. Francis, C. J. Dodge ANd J. B. GLllow \\ Department of Applied Science \\ Brookhaven National Laboratory \\ Upton, NY 11973
}

Cooperative Research and Development Agreement (CRADA) with

KEITH E. FORRESTER

Forrester Environmental Services Inc., [FESI]

Hampton, New Hampshire 03843-2008

Final Report

September 24, 1999 


\section{CONTENTS}

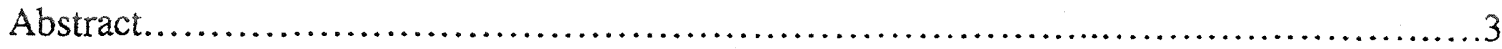

1. BNL Citric Acid Technology: Pilot Scale Demonstration...............................4

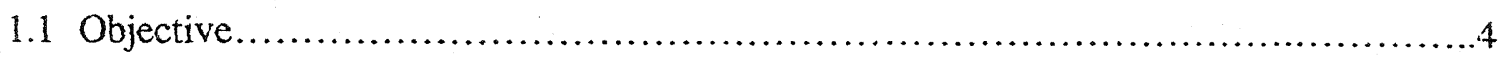

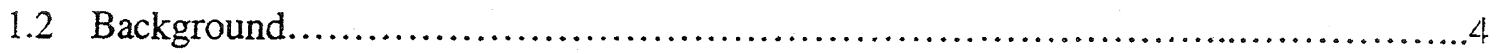

1.3 Problem Statement...........................................................

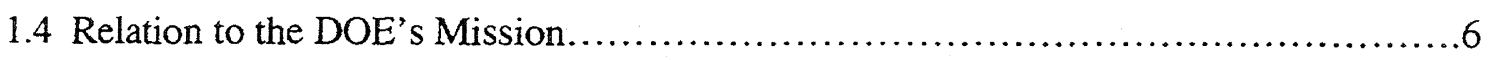

2. Experimental Approach and Results......................................?

2.1 Responsibilities................................................................

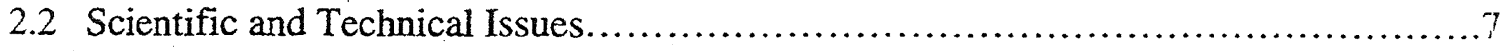

2.3 Experimental Results...................................................... 8

3. Significant Issues and Accomplishments of the BNL/FESI CRADA ................

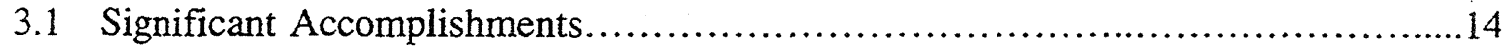

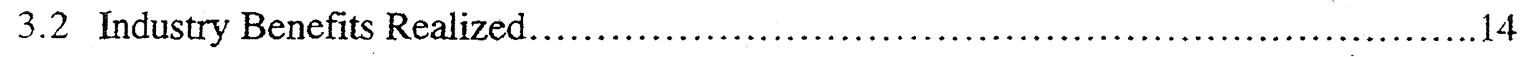

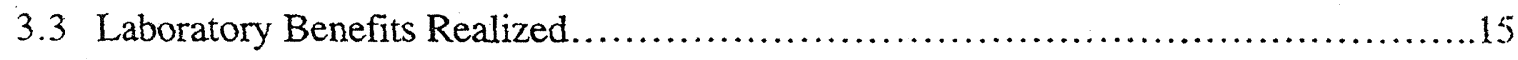

3.4 Recommended Follow-On Work............................................... 15

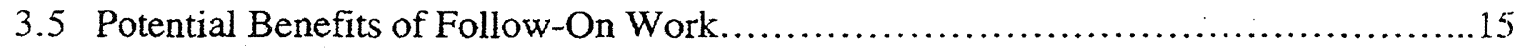

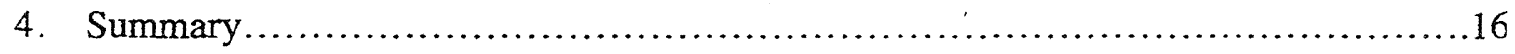

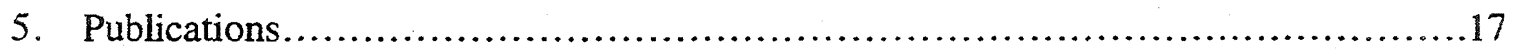

Appendix A. Field Samples Obtained From FESI................................ 18

Appendix B. Project Personnel...............................................19 


\begin{abstract}
The objective of this project is to remove toxic metals such as lead and cadmium from incinerator ash using the Citric Acid Process developed at Brookhaven National Laboratory. In this process toxic metals in bottom ash from the incineration of municipal solid waste were first extracted with citric acid followed by biodegradation of the citric acid-metal extract by the bacterium Pseudomonas fluorescens for metals recovery. The ash contained the following metals: $\mathrm{Al}, \mathrm{As}, \mathrm{Ba}, \mathrm{Ca}, \mathrm{Cd}, \mathrm{Cr}, \mathrm{Cu}, \mathrm{Fe}, \mathrm{Mg}, \mathrm{Mn}, \mathrm{Ni}, \mathrm{Pb}, \mathrm{Se}, \mathrm{Sr}, \mathrm{Ti}$, and $\mathrm{Zn}$. Optimization of the Citric Acid Process parameters which included citric acid molarity, contact time, the impact of mixing aggressiveness during extraction and pretreatment showed lead and cadmium removal from incinerator ash of $>90 \%$. Seeding the treated ash with $P$. fluorescens resulted in the removal of residual citric acid and biostabilization of any leachable lead, thus allowing it to pass EPA's Toxicity Characteristic Leaching Procedure. Biodegradation of the citric acid extract removed $>99 \%$ of the lead from the extract as well as other metals such as $\mathrm{Al}, \mathrm{Ca}, \mathrm{Cu}$, $\mathrm{Fe}, \mathrm{Mg}, \mathrm{Mn}, \mathrm{Ti}$, and $\mathrm{Zn}$. Speciation of the bioprecipitated lead by Extended X-ray Absorption Fine Structure at the National Synchrotron Light Source showed that the lead is predominantly associated with the phosphate and carboxyl functional groups in a stable form. Citric acid was completely recovered $(>99 \%)$ from the extract by sulfide precipitation technique and the extraction efficiency of recovered citric acid is similar to that of the fresh citric acid. Recycling of the citric acid should result in considerable savings in the overall treatment cost. We have shown the potential application of this technology to remove and recover the metal contaminants from incinerator ash as well as from other heavy metal bearing wastes (i.e., electric arc furnace dust from steel industry) or soils. Information developed from this project is being applied to demonstrate the remediation of lead paint contaminated soils on Long Island.
\end{abstract}




\section{BNL CITRIC ACID TECHNOLOGY: PILOT SCALE DEMONSTRATION}

\subsection{OBJECTIVE}

The overall objective of this CRADA is to remove toxic metals such as $\mathrm{Pb}$ and $\mathrm{Cd}$ from incinerator ash on a pilot plant scale using the BNL Citric Acid Process. The processes for the treatment of bottom ash, fly ash, scrubber residues, and combinations thereof will be designed, optimized, and demonstrated at a full-scale ash production facility.

Specifically in this study the following were investigated: (i) collection of ash type (bottom ash, fly ash, scrubber residues, combination ash); (ii) citrate solution contact time; (iii) TCLP and compositional change as function of dwell time and citrate concentration; (iv) citrate/metal complex solution dewatering methods (centrifuge/gravity drain); (v) metal complex recovery from solution (precipitation); and (vi) final ash handling and chemical characterization.

\subsection{BACKGROUND}

A comprehensive process (US Patent No. 5,292,456) has been developed at Brookhaven National Laboratory (BNL) to remove and recover radionuclides and toxic metals from contaminated soils, sediments, sludges and wastes. The BNL Citric Acid Process extracts metal contaminants from soil/wastes and then converts them to a concentrated and stable form. The reduction in volume and mass of the waste renders it amenable for recovery, recycling or disposal.

The overall process consists of three steps: extraction, biodegradation and photodegradation. Citric acid, a naturally occurring organic complexing agent, is used to extract metals and radionuclides from contaminated materials through the formation of water soluble metal citrate complexes. The metal citrate complexes formed may have a bidentate, tridentate, binuclear or polynuclear structure. The extract containing radionuclide/metal citrate complexes is then subjected to aerobic microbial degradation followed by photodegradation. Most of the metal citrate complexes, with the exception of uranium, undergo biodegradation and the metals are recovered in a concentrated form with the bacterial biomass. Uranium forms a binuclear complex with citric acid and is not biodegraded. Hence, it is easily separated from the rest of the metals after biodegradation. On subsequent exposure of the 
uranium containing effluent to light, the uranium citrate complex undergoes rapid photodegradation resulting in the precipitation of uranium as $\mathrm{UO}_{3} \cdot 2 \mathrm{H}_{2} \mathrm{O}$.

Preliminary studies with the municipal solid waste incinerator ash showed that the BNL Citric Acid Process is effective in removing the metals $\mathrm{Cu}, \mathrm{Mg}, \mathrm{Mn}, \mathrm{Pb}$, and $\mathrm{Zn}$ with > $90 \%$ efficiency. Biodegradation studies of the metal citrate extract by Pseudomonas fluorescens showed that the bacterium degraded the citric acid to carbon dioxide and water resulting in the precipitation of the metals. The metals present in solution were not toxic to the bacterium and were recovered along with the biomass due to precipitation, coprecipitation, and adsorption processes. These results show the potential application of this technology to remove and recover the metal contaminants from incinerator ash and from other waste forms. After heavy metals extraction, the bottom ash is more suitable for reuse in direct environment exposures such as road base and construction aggregates.

The BNL Citric Acid Process is very versatile and can be applied to various other metal contaminated materials and waste forms. It has been successfully used to treat uraniurn contaminated soils from Fernald, and Ashtabula, $\mathrm{OH}$, and a process sludge from the $\mathrm{Y}-12$ plant at Oak Ridge, TN. In addition to its wide range of applicability, the technology minimizes generation of secondary waste streams, causes little damage to the soil, and recovers environmentally and economically important metals in a concentrated form.

\subsection{PROBLEM STATEMENT}

The U.S. Supreme Court's recent ruling that incinerator ash residues must be subjected to the RCRA TCLP leaching test has forced the entire incinerator industry to rapidly evaluate and install ash stabilization processes which will render ash leaching below the regulatory limits of $5.0 \mathrm{ppm} \mathrm{Pb}$ and $1.0 \mathrm{ppm} \mathrm{Cd}$. In response to this, FESI is currently in the process of installing a variety of ash stabilization processes as remedial treatments. None of the current $\mathrm{Pb}$ and $\mathrm{Cd}$ stabilization processes used in the U.S. or the world, produce $\mathrm{a} \mathrm{Pb}$ or: $\mathrm{Cd}$ bearing ash which is less hazardous or toxic in regards to ash dermal, ingestion, or: inhalation exposure. The TCLP test is limited to evaluating leachable RCRA metals (Ag, As, $\mathrm{Ba}, \mathrm{Cd}, \mathrm{Cr}, \mathrm{Hg}, \mathrm{Pb}, \mathrm{Se}$ ), and thus ignores the hazards of incinerator ash under the other exposure routes. In addition to the ongoing need for TCLP control in the U.S. and composition control in specific states, the reuse of incinerator bottom ash (BA) is also currently criticized by environmental agencies and groups due to the $\mathrm{Pb}$ and $\mathrm{Cd}$ contents of BA. The ruling on ash is predicted to have a direct impact on the current garbage disposal 
policies in certain parts of this country. This would mean that disposal of the incinerator ash, in accordance with EPA regulations, may cost 3 to 10 times more in the future. In response to the above regulatory, political, and environmental control needs, the extraction, and hence, compositional and TCLP reduction of $\mathrm{Pb}$ and $\mathrm{Cd}$ from incinerator ash residues is a needed technology.

\subsection{RELATION TO THE DOE PROGRAM'S MISSION}

The process chemistry of BNL's citric acid technology is based on fundamental research sponsored by DOE's OHER, Subsurface Science Program. BNL Citric Acid Process has been successfully used to treat uranium contaminated soils from DOE sites. If research under the CRADA is successful, the treatment of incinerator ash will benefit DOE and other government and private operators of incinerator facilities by removing hazardous and toxic metals from ash, and hence eliminating the present environmental concerns that are associated with incinerator ash. 


\section{EXPERIMENTAL APPROACH AND RESULTS}

\subsection{RESPONSIBILITIES}

\subsubsection{BNL:}

BNL role is to provide the necessary technical support and bench scale data for pilot plant implementations of the citric acid extraction, recycling and treatment of the final effluent. The bench scale studies are directed at maximizing the extraction of $\mathrm{Pb}$ and $\mathrm{Cd}$ from ash. The metals are then recoveredand the citric acid is recycle following subsequent treatment.

\subsubsection{FESI:}

FESI's role is to collect the ash to be used in the BNL studies. A pilot scale demonstration of the BNL Citric Acid Process will be conducted at an incinerator site and an evaluation of the commercialization and engineering aspects of the technology will be made. Based upon the results of the pilot plant study a scale up of metal recovery and citric acid recovery/recycling processes will be made. An integration of extraction and recovery steps for pilot scale runs will be designed and process economics studies for commercialization of the technology will be attempted.

\subsection{SCIENTIFIC AND TECHNICAL ISSUES}

BNL investigated the following parameters to provide the critical data needed for the pilot demonstration of the project.

- analysis of bottom ash (BA), fly ash (FA) and fly ash/scrubber (FA/S) samples.

- extraction of metals from BA, FA, and FA/S with $0.5 \mathrm{M}$ citric acid for $5 \mathrm{~h}$ and the extraction efficiency of metals by citric acid.

- citric acid recovery and recycle

- effect of $\mathrm{pH}$ on precipitation of lead and recovery of citric acid.

- precipitation of $\mathrm{Pb}$ by Lime ( $\mathrm{CaO})$; Hydroxyapatite $(\mathrm{HA})$.

- precipitation of $\mathrm{Pb}$ by sulfide. 


\subsection{EXPERIMENTAL RESULTS}

2.3.1. Physical and Chemical Characterization of Bottom Ash, Fly Ash and Fly Ash/Scrubber Samples.

The BA, FA, and FA/S ash samples were provided by FESI (see Appendix A). The moisture content of the ash samples was determined by loss in weight following heating overnight at $110^{\circ} \mathrm{C}$. Samples were digested with a mixture of $\mathrm{HNO}_{3} / \mathrm{HCl} /$ perchloric acid and analyzed for major metals $\mathrm{Al}, \mathrm{Ca}, \mathrm{Fe}, \mathrm{Mg}, \mathrm{Ti}$, and $\mathrm{Zn}$ and trace metals $\mathrm{Ba}, \mathrm{Cd}, \mathrm{Cr}, \mathrm{Cu}, \mathrm{Mr}$, $\mathrm{Ni}$, and $\mathrm{Pb}$. The results are presented in Table 1 . The moisture content of the ash varied between $0.5 \%$ for the FA and $11.7 \%$ for the bottom ash. The $\mathrm{Al}$ was present in greatest amount in all samples except for the fly ash which showed high concentration of $\mathrm{Zn}$. The predominant trace metal was lead which was present in the following amounts $(\mu \mathrm{g} / \mathrm{g})$ : $\mathrm{BA}$, 1010; FA, 9070; FA/S, 3850.

\subsubsection{Extraction of Metals From Bottom Ash.}

The effect of citric acid concentration on metal extraction from the ash was determined by extracting the bottom ash for $5 \mathrm{~h}$ in the following amonts of citric acid $(\mathrm{M}): 0.05,0.1,0.2$, and 0.5 . The extraction efficiency of lead by citric acid was determined following analysis of the extract. The results are presented in Figure 1. In general, the extraction was not dependent on citric acid concentration and the extraction efficency increased in the following; order: $0.5 \mathrm{M}>0.05 \mathrm{M}>0.2 \mathrm{M}>0.2 \mathrm{M}$. The effect of citric acid molarity on extraction of other metals is presented in Table 2 .

\subsubsection{Citric Acid Recovery and Recycle.}

\subsubsection{Effect of $\mathrm{pH}$ on Precipitation of Lead and Recovery of Citric Acid.}

The possibility of precipitation of $\mathrm{Pb}$ from a $\mathrm{Pb} /$ citric acid solution was investigated using a 1:100 Pb:citric acid. The $\mathrm{pH}$ of the samples were adjusted to from $3-12$ and incubated at $30^{\circ} \mathrm{C}$ for $24 \mathrm{~h}$. Aliquots were removed periodically, filtered through a $0.45 \mu \mathrm{m}$ filter, and analyzed for $\mathrm{Pb}$. The results show that varying the $\mathrm{pH}$ of the solution did not result in effective $\mathrm{Pb}$ precipitation (Figure 2 ). 


\subsubsection{Precipitation of $\mathrm{Pb}$ by Lime.}

Lime (calcium oxide) was used to precipitate $\mathrm{Pb}$ from a $1: 100 \mathrm{~Pb}$ : citric acid at $\mathrm{pH} 3.5$. The levels of $\mathrm{Pb}$ to lime were varied from 1:5 to 1:20 molar ratio. Samples were incubated on a shaker at $120 \mathrm{rpm}$, at $30^{\circ} \mathrm{C}$ for $24 \mathrm{~h}$. Lime addition was not effective in precipitating $\mathrm{Pb}$ from $\mathrm{Pb}$ citrate solution (Figure 3 ).

\subsubsection{Precipitation of $\mathrm{Pb}$ by Hydroxylapatite (HA).}

A series of experiments were conducted to determine the effect of HA concentration on precipitation of $\mathrm{Pb}$ and citric acid. We tested $1: 1 \mathrm{~Pb}$ :citric acid to $1: 10 \mathrm{~Pb}$ :citric acid solutions. Control samples were set up without HA. A 1:1 and 1:10 mM Pb:citric acid solution was treated with varying levels of $\mathrm{HA}$ and $\mathrm{pH}$. Comparison of the results of 1:1 $\mathrm{Pb}$ :citric acid (Figure 4) and 1:10 Pb:citric acid (Figure 5) show that HA can precipitate lead from the citric acid. In the presence of excess citric acid higher amounts of HA is necessary to precipitate $\mathrm{Pb}$. The effect of $\mathrm{pH}$ was also tested on the ability of $\mathrm{HA}$ to remove lead. The efficiencies were similar at $\mathrm{pH} 3.5$ and 8.0 (data not shown).

\subsubsection{Precipitation of $\mathrm{Pb}$ by Sulfide.}

Calcium and sodium sulfide were used to precipitate $\mathrm{Pb}$ from a $1: 100 \mathrm{~Pb}$ :citric acid at $\mathrm{pH} 3.5$.

\subsection{Calcium Sulfide (CaS).}

The levels of $\mathrm{Pb}: \mathrm{CaS}$ were varied from 1:5 - 1:20 molar ratio. CaS was not effective in causing precipitation of $\mathrm{Pb}$ in any of the treatments (Figure 6). This may be due to the limited solubility of $\mathrm{CaS}$ in water.

\subsection{Sodium Sulfide $\left(\mathrm{Na}_{2} \mathrm{~S}\right)$.}

Initial qualitative study with addition of a saturated solution of $\mathrm{Na}_{2} \mathrm{~S}$ showed immediate precipitation of $\mathrm{Pb}$ from $\mathrm{Pb}$ :citric acid solution by formation of a black precipitate accompanied by $\mathrm{H}_{2} \mathrm{~S}$ odor (Figure 7). Citric acid however, remained in solution. 


\subsubsection{Biodegradation of Citric Acid Extract of BA With Metal Removal.}

The effect of bacterial activity (Pseudomonas fluorescens) on treatment of citric acid extract to remove solubilized metals was determined. The bacteria consumed all of the citric acid within $140 \mathrm{~h}$ with concomitant increase in $\mathrm{pH}$ ato 9.2 and removal of the lead within 72 hours (Figure 8). Other metals removed from the extract by bacterial activity included $\mathrm{Al}, \mathrm{Ca}$, $\mathrm{Fe}, \mathrm{Mg}, \mathrm{Cu}, \mathrm{Pb}, \mathrm{Zn}, \mathrm{Mn}$, and $\mathrm{Ti}$ (Figure 9). The weight of the final precipitate containing the metals precipitated from solution by the bacteria was $0.59 \mathrm{~g}$ per $100 \mathrm{ml}$ of extract. The quantity of metals found associated with the biomass is presented in Table. 3

\subsubsection{Determination of Stability of $\mathrm{Pb}$ in Post-Treated Samples.}

The ability of $\mathrm{P}$. fluorescens bacteria to biostabilize lead remaining in samples was tested by inoculating the treated sample and incubating the sample at room temperature. The: growth of the bacteria on the solids was measured by carbon dioxide production (Figure 10). The ability of the treatment to stabilize lead in the sample was tested by subjecting the treated sample to TCLP testing. The results are presented in Figure 11. The untreated sample: showed lead concentration at the lowest allowable regulatory limit of $5.0 \mathrm{ppm}$ (data not shown). In the treated sample however, the lead concentration in the TCLP extract decreased with increased concentration of citric acid. In the presence of $0.5 \mathrm{M}$ citric acid the lead level was an order of magnitude lower, indicating lead removal from the waste. The other regulatory metals, excluding $\mathrm{Hg}$ which was not analyzed, were below the regulatory limits in both samples (data not shown).

\subsubsection{Characterization of $\mathrm{Pb}$ Associated With the Biomass After Biodegradation of Citric} Acid Extract.

The speciation of the lead remaining after biodegradation treatment was determined by $\mathrm{X}$-ray absorption spectroscopy (XAS) technique. Comparison of $\mathrm{Pb} \mathrm{L}_{\mathrm{III}}$ edge EXAFS spectra of i) bacterial biomass; and ii) in solids obtained after bidoegradation of citric acid extract of $\mathrm{Pb}$ containing MSWI bottom ash with lead acetate, lead phosphate, lead oxide, lead hydroxide, and lead dioxide standards was made (Figure 12). $\mathrm{Pb}$ association with the samples can be readily classified by phase matching of the electronic wave of the spectra. $\mathrm{Pb}$ association with a carboxylate functional group is clearly indicated for the biomass, and phosphate ligand for the biotreated ash. 


\subsubsection{Inoculum Preparation and Cost Estimate}

\subsubsection{Inoculum.}

Culture Pseudomonas fluorescens biovar II (ATCC 55241) in modified Simmon's citrate medium containing (g): citric acid, $8 ; \mathrm{MgSO}_{4}, 0.8 ; \mathrm{NH}_{4} \mathrm{Cl}, 4 ; \mathrm{KH}_{2} \mathrm{PO}_{4}, 4 ; \mathrm{K}_{2} \mathrm{HPO}_{4}$, 4; deionized water to one gallon. The $\mathrm{pH}$ of medium is adjusted to 6.1 with $\mathrm{NaOH}$ and the bacterium is grown overnight at $26 \pm 1^{\circ} \mathrm{C}$ in the dark on a rotary shaker. One liter of inoculum. gives an optical density of 0.6 at $40 \mathrm{~h}$ and contains $0.25 \mathrm{~g}$ dry weight bacteria.

\subsubsection{Inoculum Size.}

Biodegradation. One gallon of inoculum is added to 20 gallons of the metal containing $0.05 \mathrm{M}$ citric acid extract and the mixture is incubated at $26 \pm 1^{\circ} \mathrm{C}$ until the citric acid is completely degraded (approximately 3 to 5 days). The liquid is decanted from the solid and used for recycle. The solid is disposed of or recycled.

\subsubsection{Assumptions.}

Ash weight, 1.0 pounds; extract volume, 2.4 gallons ( $1: 20$ solid/liquid ratio); inoculum size (5\%), 0.12 gallons. Cost of bulk chemicals ( $\$$, Sigma Chemical Co.): citric acid, $53.35 / 5 \mathrm{~kg}$; magnesium sulfate, $105.25 / 5 \mathrm{~kg}$; ammonium chloride, $48.45 / 2.5 \mathrm{~kg}$; potassium hydrogen phosphate monobasic, $190.65 / 10 \mathrm{~kg}$; potassium hydrogen phosphate dibasic, $329.00 / 10 \mathrm{~kg}$; sodium hydroxide, $93.45 / 5 \mathrm{~kg}$.

\subsubsection{Ash Stabilization.}

One half gallon of inoculum is added to 8 gallons of deionized water and mixed with 8.3 pounds of the extracted waste. The liquid is decanted from the solid and recycled. The solid is incubated for several days and checked for TCLP metals. The stabilized material is then disposed of or reused.

\subsubsection{Chemical Costs.}

Ash weight, 1.0 pounds; extract volume, 2.4 gallons (1:20 solid/liquid ratio); inoculum size $(5 \%), 0.12$ gallons. Cost of bulk chemicals ( $\$$, Sigma Chemical Co.): citric 
acid, $53.35 / 5 \mathrm{~kg}$; magnesium sulfate, $105.25 / 5 \mathrm{~kg}$; ammonium chloride, $48.4572 .5 \mathrm{~kg}$; potassium hydrogen phosphate monobasic, $190.65 / 10 \mathrm{~kg}$; potassium hydrogen phosphate dibasic, $329.00 / 10 \mathrm{~kg}$; sodium hydroxide, $93.45 / 5 \mathrm{~kg}$. The cost of materials for one gallon of inoculum was calculated from the cost per kilogram of chemical: citric acid, $\$ 10.67 ; \mathrm{MgSO}_{4}$, $\$ 21.00 ; \mathrm{NH}_{4} \mathrm{Cl}, \$ 19.40 ; \mathrm{KH}_{2} \mathrm{PO}_{4}, \$ 19.05 ; \mathrm{K}_{2} \mathrm{HPO}_{4}, \$ 33.00 ; \mathrm{NaOH}, \$ 18.70$. The total cost is $47.8 \mathrm{c} /$ gallon. Treatment of 1 ton ash requires 241 gallons of inoculum (5\%) at a total cost of $\$ 115.00$.

\subsubsection{Inoculum Preparation Time.}

Preparation of one gallon inoculum requires approximately two days of labor which includes media preparation, incubation of culture, centrifugation of cells, and packaging for shipment to Forrester Environmental Inc., Hampton, NH.

\subsection{TREATMENT OF OTHER WASTE FORMS}

We have also performed studies on the following types of waste materials including electric arc furnace dust, arsenic contaminated wood ash, and lead paint contaminated soils.

\subsubsection{Electric Arc Furnace Dust.}

The utilization of the BNL Citric Acid Process for recovery of metals from waste materials derived from the reclamation of steel scrap has been investigated. The removal of various metals from the scrap is presented in Table 4. Excellent removal of $\mathrm{Pb}(98 \%) \mathrm{Ca}$ (99\%), and $\mathrm{Sr}(100 \%)$ was obtained, with smaller but significant amounts of $\mathrm{Al}(65 \%), \mathrm{Cd}$ $(59 \%)$. Ti (74\%), and Zn (53\%).

\subsubsection{Wood Chip Ash.}

Arsenic contaminated wood chip ash derived from sugar cane crop residues was completely remediated with removal of all the arsenic (103\%). See Table 5.

\subsubsection{Lead Contaminated Soils.}

Soils contaminated with lead from the flaking of lead-based paint around a power generation facility was remediated using the BNL Citric Acid Process. The treated soil was 
subjected to the EPA Toxicity Characteristic Leaching Procedure (TCLP). The results for various soil particle diameters are presented in Table 6 . All of the size fractions $<3 / 8$ " passed. Larger size fraction $(>3 / 8 ")$ contained small amount of lead and did not need remediation. 


\section{SIGNIFICANT ISSUES AND ACCOMPLISHMENTS OF THE BNL/FESI CRADA}

\subsection{SIGNIFICANT ACCOMPLISHMENTS}

\subsubsection{Brookhaven National Laboratory}

BNL/FESI has developed a comprehensive process for the removal of lead from MSWI bottom ash (Figure 13, Process Flow Chart). BNL has made significant progress in laboratory tests to optimize the citric acid process for removing toxic metals from incinerator ash. Laboratory tests have shown that the extraction process is very effective $(>70 \%)$ for $\mathrm{Cd}$, $\mathrm{Pb}$, and $\mathrm{Zn}$, and treated ash has passed TCLP tests. The most significant development was the successful testing and effectiveness of recycled citric acid. The effectiveness of recycled citric acid is essential to scale-up of the process for field demonstration.

\subsubsection{Forrester Environmental Services INC., [FESI]}

The bottom ash (BA) extraction technology is under corporate review by three incinerator operators, EAC, Monteney, and BFI, for use at incinerator facilities in the USA FESI has partnered with EAC. The implementation of contracts is stagnant due to unresolved state positions on $\mathrm{BA}$ recycling.

FESI has partnered with a Swiss firm for marketing the extraction technology for incinerator BA and FASR. The Swiss, German, and Sweden waste management regulations require reduction of metals for reuse or land disposal at local landfills. These markets look promising and research and marketing efforts are underway.

\subsection{INDUSTRY BENEFITS REALIZED}

A major national concern is the remediation of contaminated materials, soils, and water, and the safe and economical disposal of wastes containing radionuclides and toxic metals. Because these problems are pervasive, new innovative treatment and remediation technologies, including bioremediation, are being developed. For decontamination of the waste material, the toxic contaminants must be removed. It would be desirable and beneficial to the environment to provide a comprehensive method for the removal of toxic metals. 


\subsection{LABORATORY BENEFITS REALIZED}

The Laboratory has a significant quantity of hazardous and radionuclide contaminate materials and soils. The benefits would include on-site remediation of the wastes which would save the substantial costs involved in off-site disposal.

\subsection{RECOMMENDED FOLLOW-ON WORK}

Research to date on the CRADA has revealed that dissolution and selective complexation of $\mathrm{Pb}$ and other toxic metals from the waste matrix are the critical steps needed further work to fine tune the BNL Citric Acid Treatment Process. This would allow us to reduce the initial extraction time, the amount of citric acid, sludge production and overall treatment cost. Pretreatment of lead containing samples shouldinvestigated prior to citric acid extraction in order to maximize the dissolution of lead and other toxic elements. Determine the ability of citric acid to selectively complex and remove $\mathrm{Pb}$ and other toxic metals. Posttreatment methods should utilized to maximize biostabilization of $\mathrm{Pb}$ and control of $\mathrm{pH}$. FESI's effortto do pilot studies at an incinerator facility in Massachusetts has been put on hold. due to lack of industry's commitment. In the future under a separate funding from FESI BNL may provide technical assistance to FESI in the pilot demonstration tests.

\subsection{POTENTIAL BENEFTTS OF FOLLOW-ON WORK}

There are several remediation techniques proposed to treat toxic metals and radionuclides from soils and wastes. They suffer from severe drawbacks because of the use of harsh chemicals such as strong mineral acids (sulfuric or hydrochloric) which not only leach the important mineral constituents but generate acidic wastes. Furthermore, the treated soil or material may be unfit for reuse. In this study we propose to extract the radionuclides and toxic metals from ash by using citric acid. Citric acid is a naturally occurring compound capable of complexation of metal ions and undergoes rapid biodegradation. In addition to its wide range of applicability, the technology minimizes generation of secondary waste streams, causes little damage to the soil, and recovers environmentally and economically important metals in a concentrated form. 


\section{SUMMARY}

BNL Citric Acid Process is effective for treatment of MSW incinerator ash. $\mathrm{Pb}$ was extracted from the bottom ash with $90 \%$ efficiency, while Cd was extracted from the bottom ash with $>81 \%$ efficiency. Citric acid was recovered completely ( $>99 \%)$ from the extract by sodium sulfide treatment. Extraction efficiency of recycled (recovered) citric acid is equal to or greater than the fresh citric acid. Biodegradation of the extract resulted in the removal of $\mathrm{Pb}$ $(100 \%)$ and $\mathrm{Cd}(100 \%)$ in fly ash and $\mathrm{Pb}(97 \%)$ and $\mathrm{Cd}(70 \%)$ in bottom ash. Treated ash passed TCLP. Characterization of $\mathrm{Pb}$ associated with the biomass after biodegradation of citric acid extract by XAS and XPS showed that $\mathrm{Pb}$ was predominantly associated with the phosphate as an insoluble complex. We have demonstrated the feasibility of removal of residual citric acid in the treated solids by seeding with $P$. fluorescens and biostabilization of any remaining leachable $\mathrm{Pb}$. 


\section{PUBLICATIONS}

Francis, A. J. and Dodge, C. J. Waste site reclamation with recovery of radionuclides and metals. U.S. Patent No. 5,292,456, March 8, 1994.

Francis, A. J., Wang, X. C., and Forrester, K. Removal and recovery of toxic metals from incinerator bottom-ash. Presented at American Chemical Society Meeting on "Energy Technologies in Hazardous Waste Management VI," Atlanta, GA, Sept. 19-21, 1994.

Francis, A.J. and C.J. Dodge. Bioprecipitation of Lead from Citric Acid Extract by Pseudomonas fluorescens (in preparation). 


\section{Appendix A. Field Samples Obtained from FESI}

May 22, 1996

LIQUTD SAMPLES

EACO, Pittsfield, MA

- On-site extraction of MSW Incinerator Ash

- in tank-extraction time $(5,10,15,20,25,30,46,60 \mathrm{~min}$.$) -$

2 in-tank wash time $(5,20$ minutes $)$

3 - citric acid $(0.1,0.5 \mathrm{M})$

SOLID SAMPLES

BAU (1.1 kg), WBAU (1.1 kg), BAF (0.9 kg), extracted ash (8 samples), ash extracts ( 8 samples)

June 25, 1996

LIQUID SAMPLES

citric acid extracts (16 samples)

SOLID SAMPLES

BAU (4 kg), WBAU (15 kg), extracted ash (16 samples) 


\section{Appendix B. Project Personnel}

1. PROJECT PERFORMANCE PERIOD: FY95 - FY 98

TOTAL FUNDING: $\$ 438,000$

2. PRINCIPAL INVESTIGATORS

A.J. FRANCIS

Brookhaven National Laboratory

Department of Applied Science

Telephone Number: (516) 344-4534

COOPERATIVE RESEARCH AND DEVELOPMENT AGREEMENT (CRADA) WTTH

KEITH E. FORRESTER

Forrester Environmental Services, Inc.[FESI]

883 Ocean Blvd., Hampton, NH 03843

Telephone Number: (603) 929-5065

3. PRINCIPAL PROJECT PERSONNEL

C.J. DODGE (Chemistry Asssociate)

J. B. GILLOW (Chemistry Associate)

4. ADDITIONAL PROJECT PERSONNEL

Collaborator: Professor Clive R. Clayton, Department of Material Science, SUNY Stony Brook, NY. Speciation by X-ray photoelectron spectroscopy (XPS) and corrosion studies. 
Table 1. Characterization of municipal solid waste incinerator ash (MSWI)

Bottom ash

Fly ash

Fly ash scrubber

Physical

Moisture content (\%)

11.7

0.5

2.3

Chemical

Major metals (\%)

$\begin{array}{llll}\mathrm{Al} & 3.52 \pm 0.06 & 3.50 \pm 0.04 & 2.95 \pm 0.04 \\ \mathrm{Ca} & 1.40 \pm 0.01 & 1.32 \pm 0.03 & 2.20 \pm 0.42 \\ \mathrm{Fe} & 1.24 \pm 0.04 & 0.29 \pm 0.00 & 0.40 \pm 0.00 \\ \mathrm{Mg} & 0.71 \pm 0.02 & 0.67 \pm 0.03 & 0.58 \pm 0.03 \\ \mathrm{Ti} & 0.19 \pm 0.07 & 0.07 \pm 0.01 & 0.41 \pm 0.09 \\ \mathrm{Zn} & 0.47 \pm 0.02 & 4.74 \pm 0.24 & 1.24 \pm 0.02\end{array}$

Trace metals ( $\mu \mathrm{g} / \mathrm{g}$ dry wt.)

$\begin{array}{llll}\mathrm{Ba} & 827 \pm 178 & 433 \pm 8 & 355 \pm 13 \\ \mathrm{Cd} & 22.0 \pm 1.1 & 578 \pm 29 & 218 \pm 10 \\ \mathrm{Cr} & 149 \pm 18 & 232 \pm 42 & 216 \pm 32 \\ \mathrm{Cu} & 548 \pm 79 & 1300 \pm 30 & 460 \pm 3 \\ \mathrm{Mn} & 578 \pm 15 & 573 \pm 4 & 277 \pm 12 \\ \mathrm{Ni} & 72.0 \pm 0.8 & 93.9 \pm 3.1 & 28.0 \pm 3.1 \\ \mathrm{~Pb} & 1010 \pm 50 & 9070 \pm 230 & 3850 \pm 76\end{array}$


Table 2. Metal extraction efficiencies using BNL Citric Acid Process (10\% w/v)

\begin{tabular}{|c|c|c|c|c|c|c|}
\hline \multirow[b]{2}{*}{ Metal } & \multicolumn{3}{|c|}{ Bottom Ash } & \multicolumn{3}{|c|}{ Fly Ash } \\
\hline & $\begin{array}{l}\text { Total } \\
\text { Metal } \\
\end{array}$ & $\begin{array}{l}\text { After } \\
\text { extraction } \\
\text { wt. - }\end{array}$ & $\begin{array}{c}\text { Removal } \\
(\%)\end{array}$ & $\begin{array}{l}\text { Total } \\
\text { Metal }\end{array}$ & $\begin{array}{l}\text { After } \\
\text { extraction } \\
\text { y wt. }\end{array}$ & $\begin{array}{c}\text { Removal } \\
(\%)\end{array}$ \\
\hline $\mathrm{Al}$ & $35200 \pm 600$ & $22100 \pm 1100$ & 37.2 & $35000 \pm 400$ & $22300 \pm 1000$ & 36.3 \\
\hline $\mathrm{Ba}$ & $827 \pm 178$ & $573 \pm 47$ & 30.7 & $433 \pm 8$ & $323 \pm 42$ & 25.4 \\
\hline $\mathrm{Cd}$ & $22.0 \pm 1.1$ & $5.3 \pm 0.2$ & 75.9 & $578 \pm 29$ & $18.7 \pm 0.2$ & 96.8 \\
\hline $\mathrm{Ca}$ & $14000 \pm 100$ & $7060 \pm 50$ & 49.6 & $13100 \pm 300$ & $9130 \pm 1280$ & 30.3 \\
\hline $\mathrm{Cr}$ & $148 \pm 18$ & $74.7 \pm 6.6$ & 49.5 & $232 \pm 42$ & $103 \pm 4$ & 55.6 \\
\hline $\mathrm{Cu}$ & $548 \pm 79$ & $333 \pm 23$ & 39.2 & $1300 \pm 30$ & $253 \pm 6$ & 80.5 \\
\hline $\mathrm{Mg}$ & $7140 \pm 170$ & $2690 \pm 50$ & 62.3 & $6650 \pm 260$ & $2200 \pm 100$ & 66.9 \\
\hline $\mathrm{Mn}$ & $578 \pm 15$ & $225 \pm 6$ & 61.1 & $573 \pm 4$ & $249 \pm 7$ & 56.5 \\
\hline $\mathrm{Ni}$ & $72.0 \pm 0.8$ & $37.3 \pm 1.3$ & 48.2 & $93.9 \pm 3.1$ & $50.7 \pm 2.1$ & 46.0 \\
\hline $\mathbf{P b}$ & $1010 \pm 50$ & $311 \pm 12$ & 69.2 & $9070 \pm 230$ & $4420 \pm 190$ & 51.3 \\
\hline Zn & $4740 \pm 240$ & $1010 \pm 30$ & 78.7 & $47400 \pm 24$ & $7420 \pm 110$ & 84.3 \\
\hline
\end{tabular}


Table 3. Metals present in biomass after biodegradation of $0.05 \mathrm{M}$ WBAU ash citric acid extract.*

\begin{tabular}{cc}
\hline Metal & $\begin{array}{c}\text { Concentration } \\
\mu \text { g/g dry wt. }\end{array}$ \\
\hline $\mathrm{Al}$ & 24800 \\
$\mathrm{As}$ & $<2.5$ \\
$\mathrm{Ba}$ & 320 \\
$\mathrm{Ca}$ & 52400 \\
$\mathrm{Cd}$ & 12.0 \\
$\mathrm{Cr}$ & $<0.25$ \\
$\mathrm{Cu}$ & 2710 \\
$\mathrm{Fe}$ & 5160 \\
$\mathrm{Mg}$ & 7080 \\
$\mathrm{Mn}$ & 439 \\
$\mathrm{Ni}$ & $<2.5$ \\
$\mathrm{~Pb}$ & 2230 \\
$\mathrm{Se}$ & $<2.5$ \\
$\mathrm{Sr}$ & 404 \\
$\mathrm{Ti}$ & 41.9 \\
$\mathrm{Zn}$ & 3150 \\
\hline
\end{tabular}

*biomass weight, $0.59 \mathrm{~g} / 100 \mathrm{ml}$ (includes ash fines plus cells). 
Table 4. Extraction of metals from electric arc furnace (EAF) dust by citric acid*.

\begin{tabular}{|c|c|c|}
\hline Metal & $\begin{array}{c}\text { Total metal } \\
\text {---ug/g dry wt. }\end{array}$ & $\begin{array}{c}\text { Extraction } \\
(\%)\end{array}$ \\
\hline $\mathrm{Ag}$ & $40 \pm 8$ & $<1$ \\
\hline $\mathrm{Al}$ & $4270 \pm 10$ & 49 \\
\hline As & $75 \pm 43$ & $<1$ \\
\hline $\mathrm{Ba}$ & $78.0 \pm 1.0$ & $<1$ \\
\hline $\mathrm{Ca}$ & $90000 \pm 100$ & 84 \\
\hline $\mathrm{Cd}$ & $190 \pm 1$ & 81 \\
\hline Co & $<2$ & $-\cdots$ \\
\hline $\mathrm{Cr}$ & $6200 \pm 210$ & 3 \\
\hline $\mathrm{Cu}$ & $1460 \pm 20$ & 17 \\
\hline $\mathrm{Fe}$ & $336000 \pm 10000$ & 6 \\
\hline $\mathrm{Mg}$ & $16200 \pm 100$ & 24 \\
\hline $\mathrm{Mn}$ & $29200 \pm 400$ & 11 \\
\hline $\mathrm{Ni}$ & $188 \pm 28$ & $<1$ \\
\hline $\mathrm{Pb}$ & $7200 \pm 100$ & 95 \\
\hline $\mathrm{Se}$ & $42600 \pm 1900$ & $<1$ \\
\hline $\mathrm{Sr}$ & $43.6 \pm 0.1$ & $<0.2$ \\
\hline $\mathrm{Ti}$ & $418 \pm 3$ & 55 \\
\hline $\mathrm{Zn}$ & $53900 \pm 1400$ & 36 \\
\hline
\end{tabular}

$* 100 \mathrm{~g}$ EAF dust extracted with $2 \mathrm{~L} 0.5 \mathrm{M}$ citric acid ( $\mathrm{pH}$ unadjusted) and filtered through $0.7 \mu \mathrm{m}$ filter. 
Table 5. Extraction efficiency of arsenic from wood chip ash.

\begin{tabular}{lc}
\hline Treatment & Arsenic (ug/g) \\
\hline Total Arsenic & $338 \pm 5$ \\
Extracted Arsenic & $348 \pm 8$ \\
Removal & $103 \%$ \\
\hline
\end{tabular}

Sample extracted (in duplicate) in $0.5 \mathrm{M}$ citric acid for 19 hours. 
Table 6. Removal of lead from contaminated soil ${ }^{1}$.

\begin{tabular}{ccccc}
\hline $\begin{array}{c}\text { Soil sample } \\
\text { (particle size fraction) }\end{array}$ & $\begin{array}{c}\text { Total } \\
\text { lead } \\
(\mathrm{ppm})\end{array}$ & $\begin{array}{c}\text { Lead } \\
\text { removed } \\
(\%)\end{array}$ & $\begin{array}{c}\text { Residual Pb } \\
(\mathrm{ppm})\end{array}$ & $\begin{array}{c}\text { TCLP test } \\
(\mathrm{mg} / \mathrm{L})\end{array}$ \\
\hline$<3 / 8^{\prime \prime}$ & 1810 & 77 & $422 \pm 64$ & 1.6 (pass) \\
$<3 / 8^{\prime \prime}$ & $1820^{3}$ & 81 & $346 \pm 6$ & 1.0 (pass) \\
$<2 \mathrm{~mm}$ & $1820 \pm 80$ & 74 & $471 \pm 138$ & nd \\
$<2 \mathrm{~mm}$ & $1800 \pm 120$ & 77 & $423 \pm 65$ & 1.3 (pass) \\
Average & $\mathbf{1 8 1 0 \pm 1 0}$ & $77 \pm 2$ & $415 \pm 68$ & passes TCLP \\
\hline
\end{tabular}

${ }^{1}$ Visible paint chips were removed prior to treatment.

${ }^{2}$ Bioprecipitation and/or chemical precipitation recovered $>99 \%$ of lead from the extract.

${ }^{3}$ TCLP for lead is $5.0 \mathrm{mg} / \mathrm{L}$. nd = not determined. 


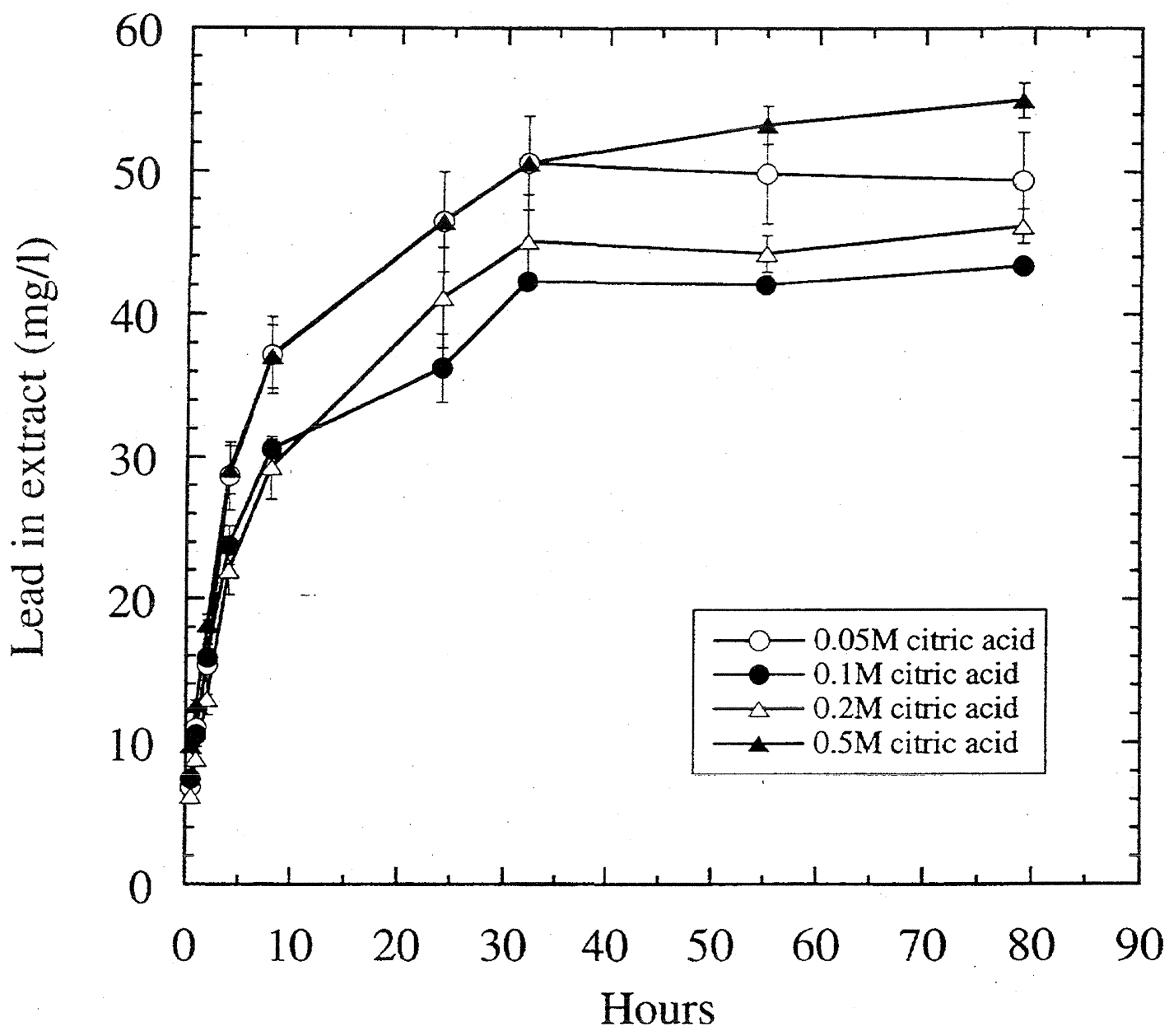

Figure 1. Effect of citric acid concentration on lead removal from MSWI bottom ash 


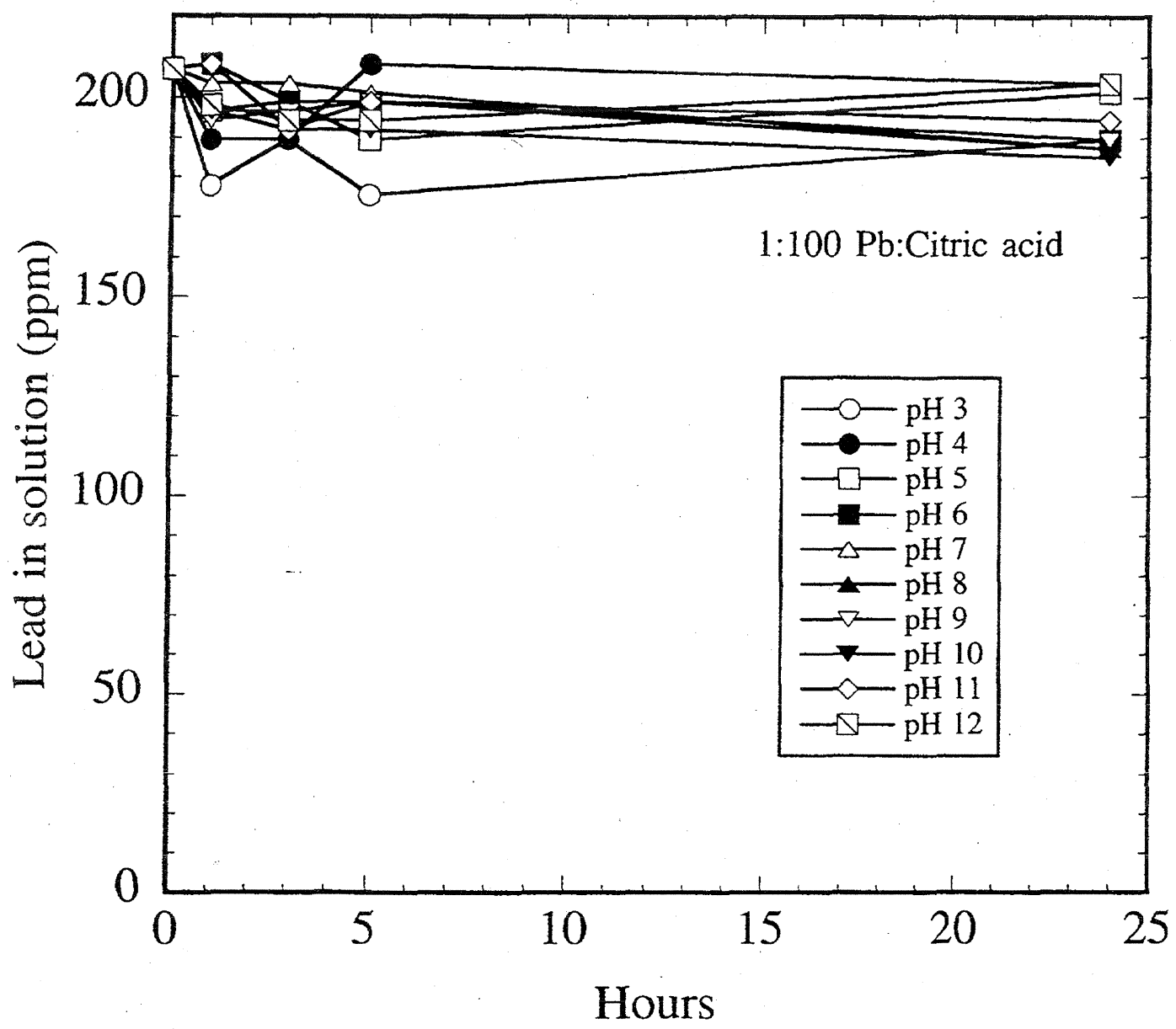

Figure 2. Effect of $\mathrm{pH}$ on precipitation of lead and recovery of citric acid 


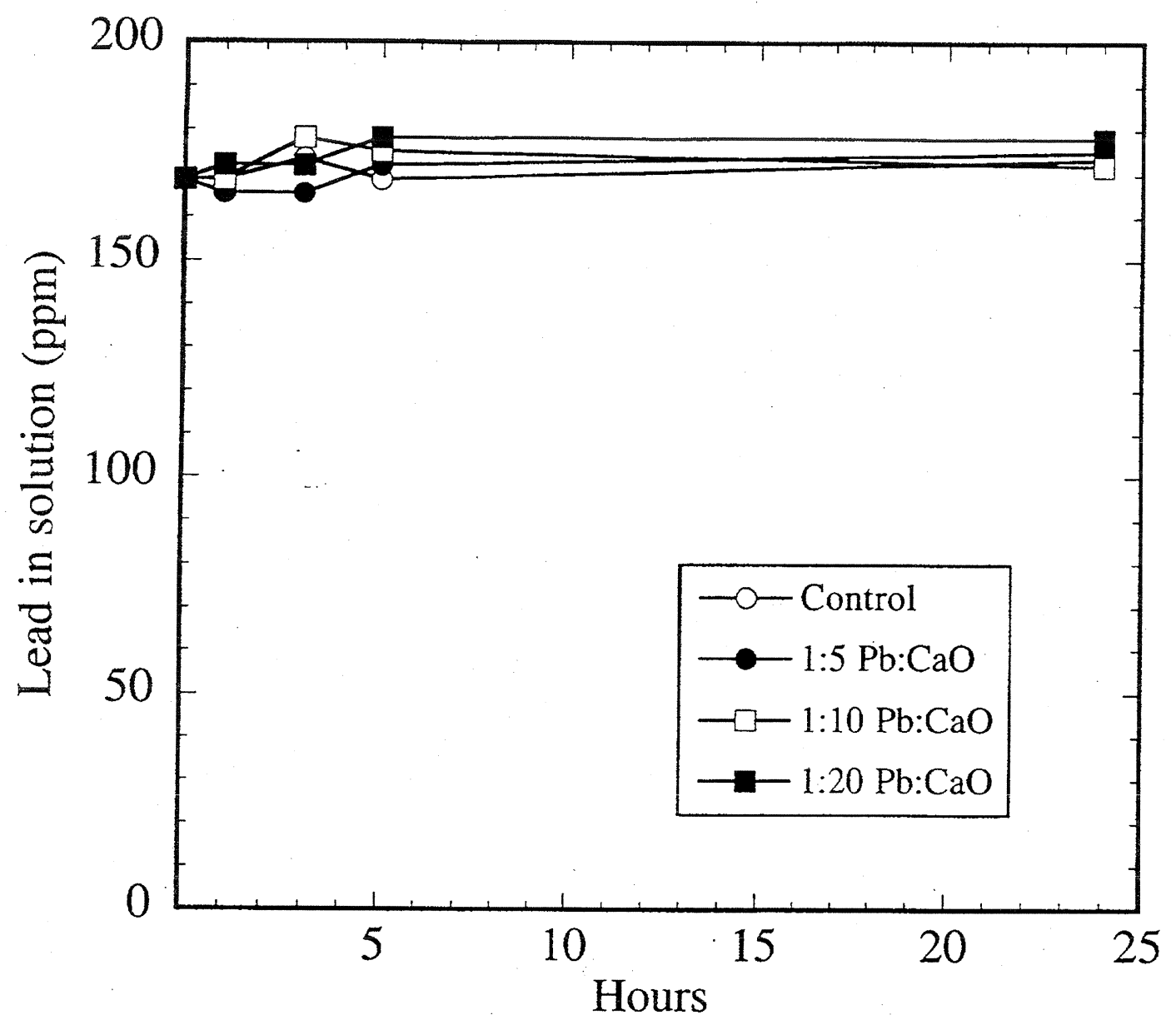

Figure 3. Effect of lime on precipitation of $1: 100 \mathrm{~Pb}$ :citric acid at $\mathrm{pH} 3.5$ 


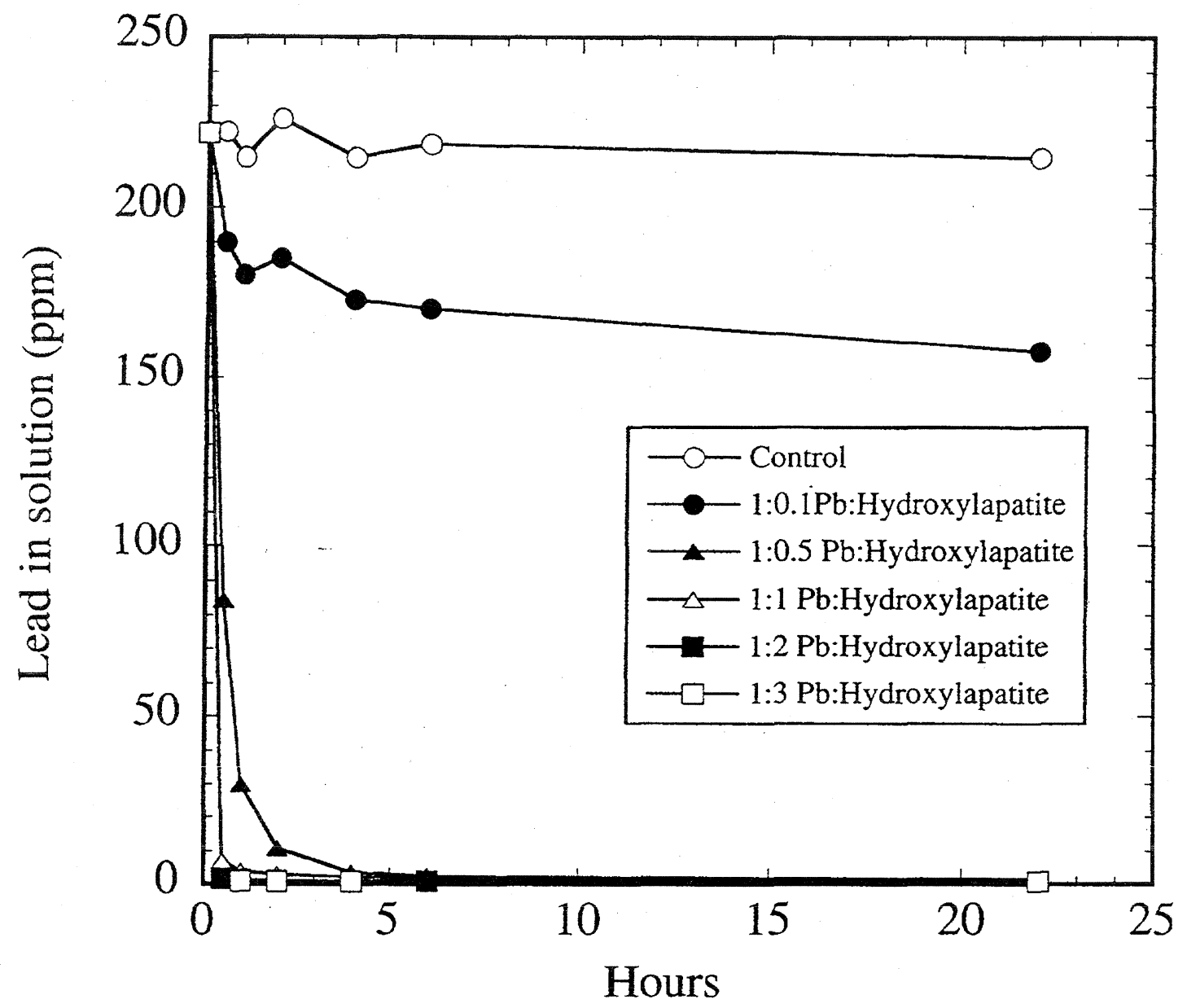

Figure 4. Effect of hydroxylapatite on precipitation of $1: 1 \mathrm{~Pb}$ :citric acid at $\mathrm{pH} 3.5$ 


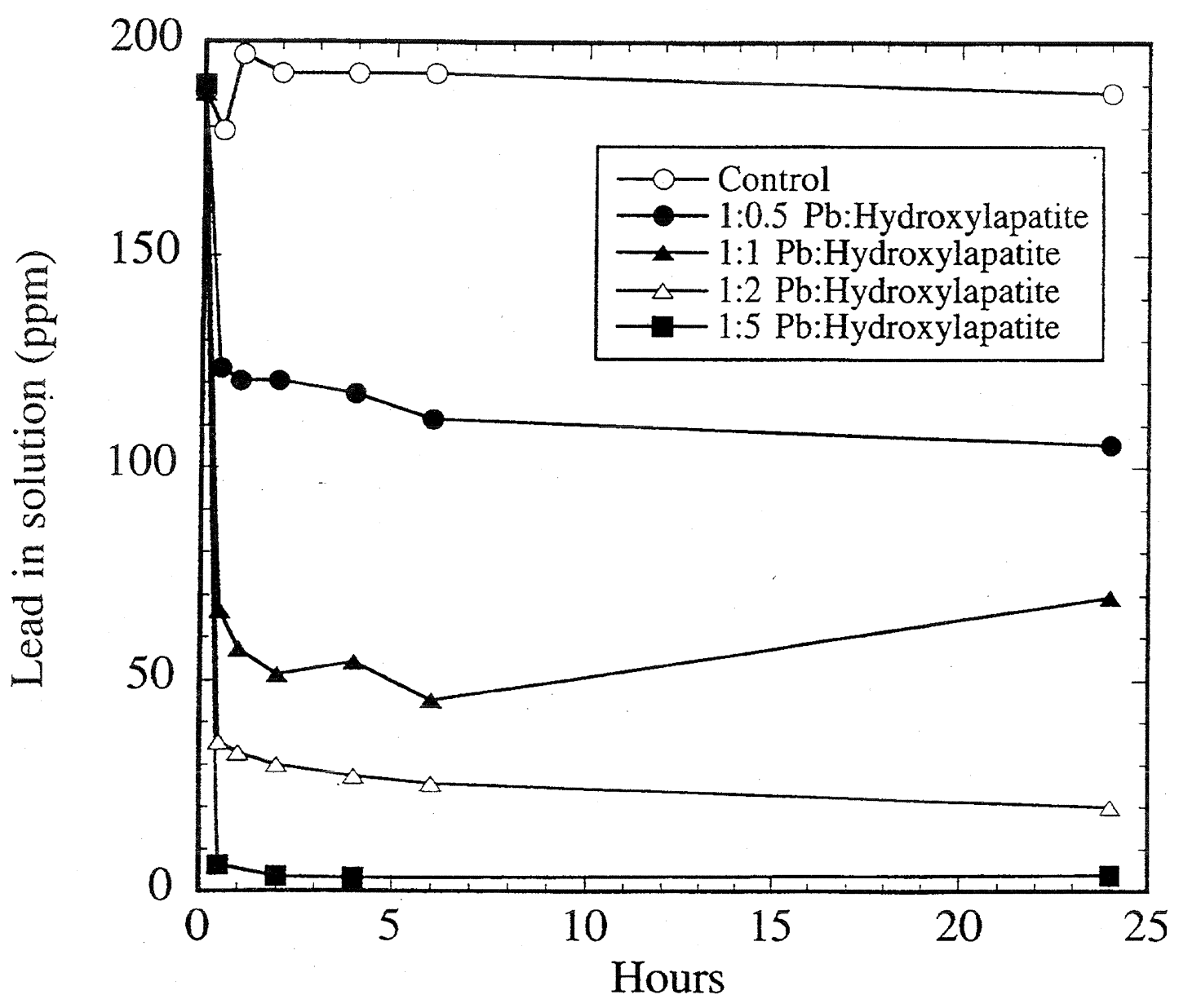

Figure 5. Effect of hydroxylapatite concentration on precipitation of $1: 10 \mathrm{~Pb}$ :citric acid at $\mathrm{pH} 3.5$ 


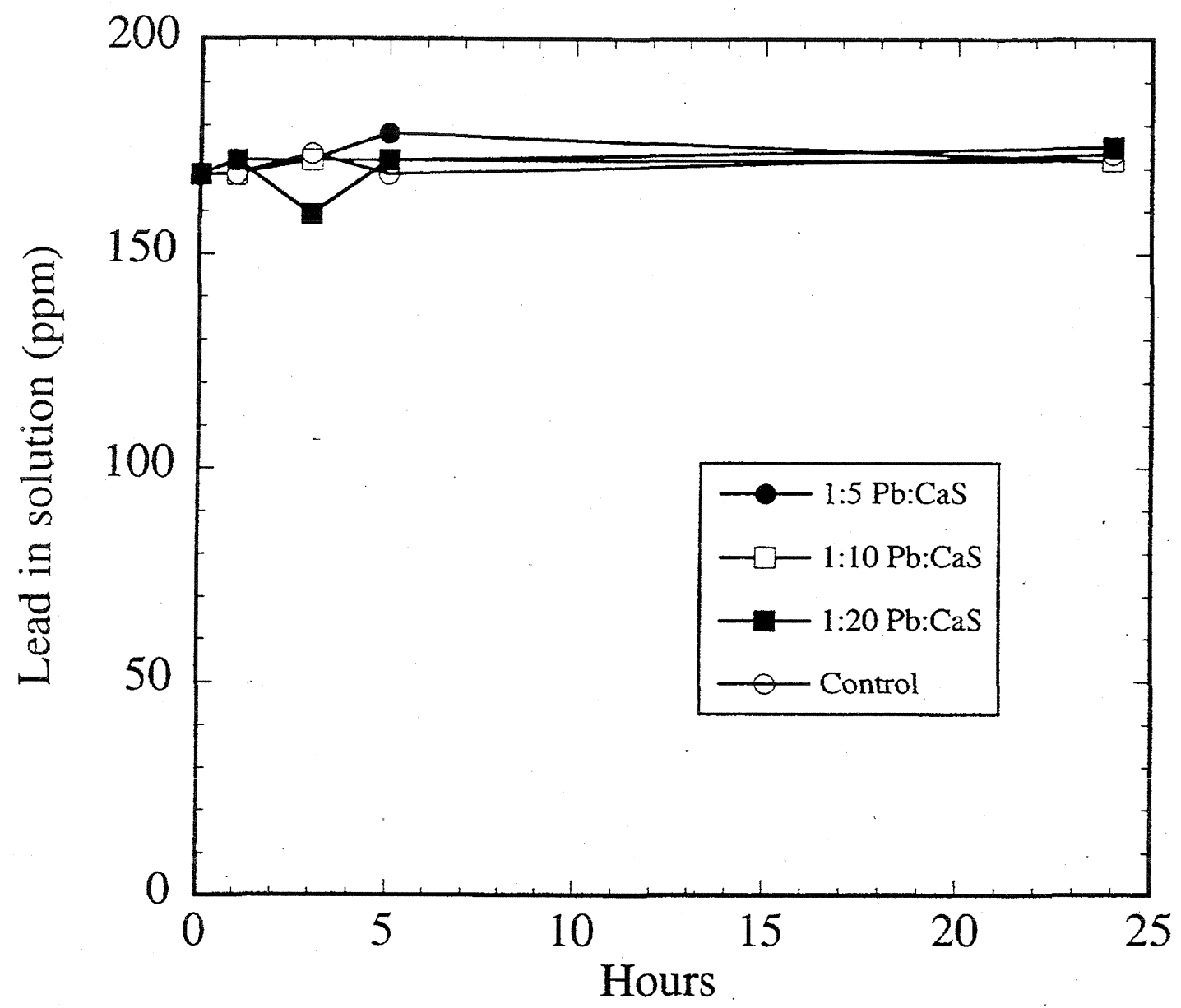

Figure 6. Effect of calcium sulfide on precipitation of $1: 100 \mathrm{~Pb}$ :citric acid at $\mathrm{pH} 3.5$ 


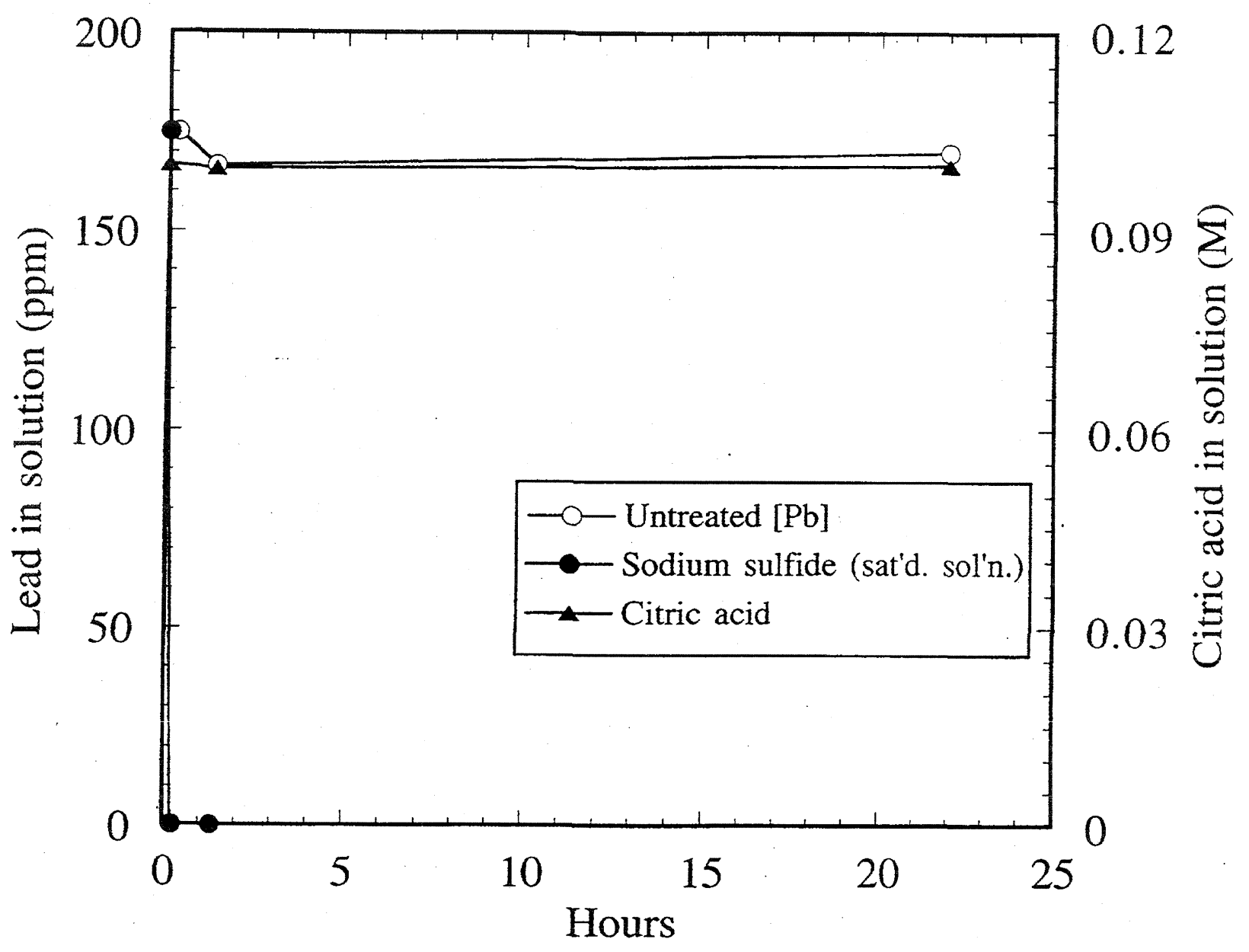

Figure 7. Effect of sodium sulfide on precipitation of $1: 100 \mathrm{~Pb}$ :citric acid at $\mathrm{pH} 3.5$ 

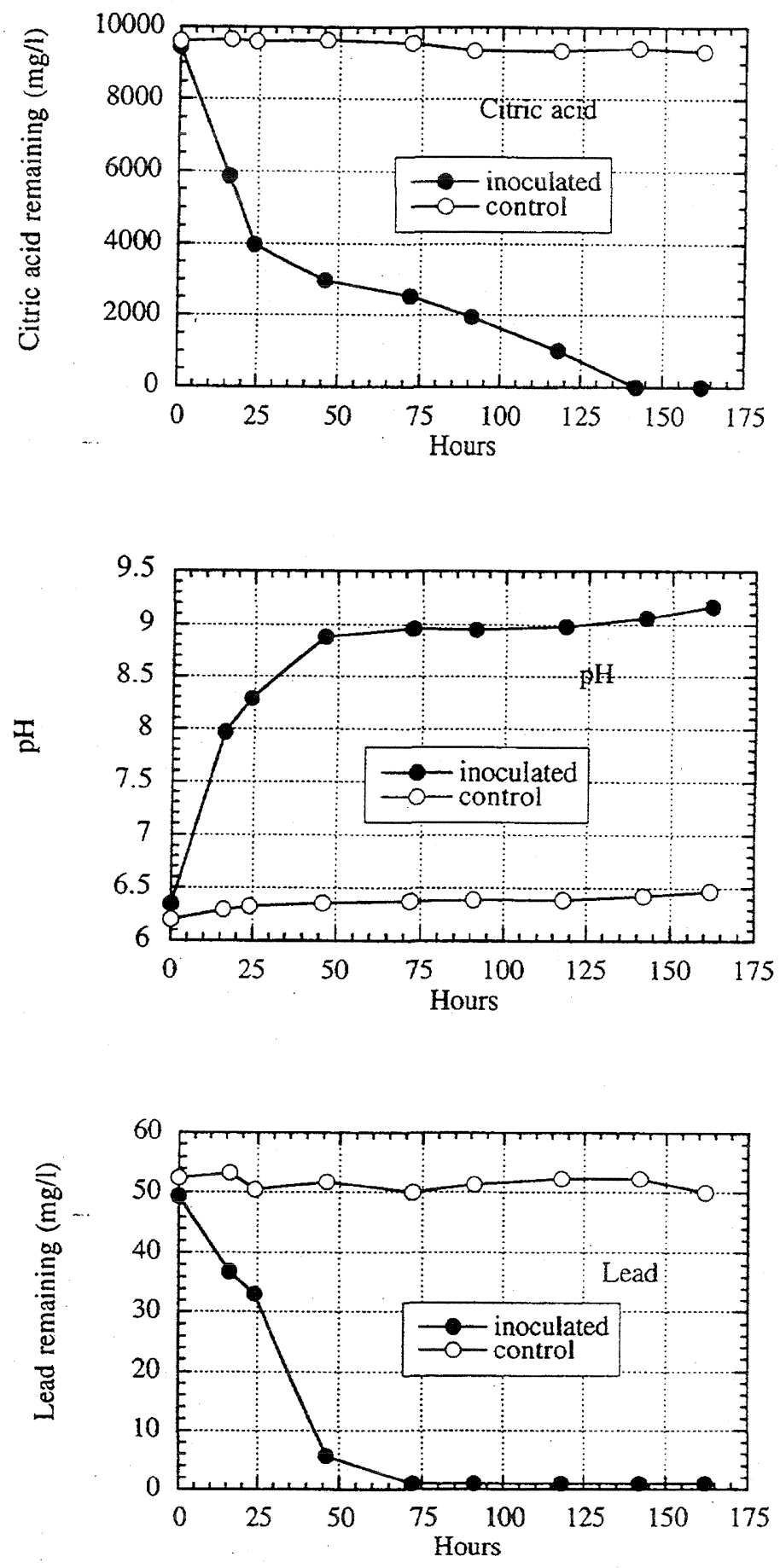

Figure 8. Biodegradation of citric acid extract from bottom ash. 

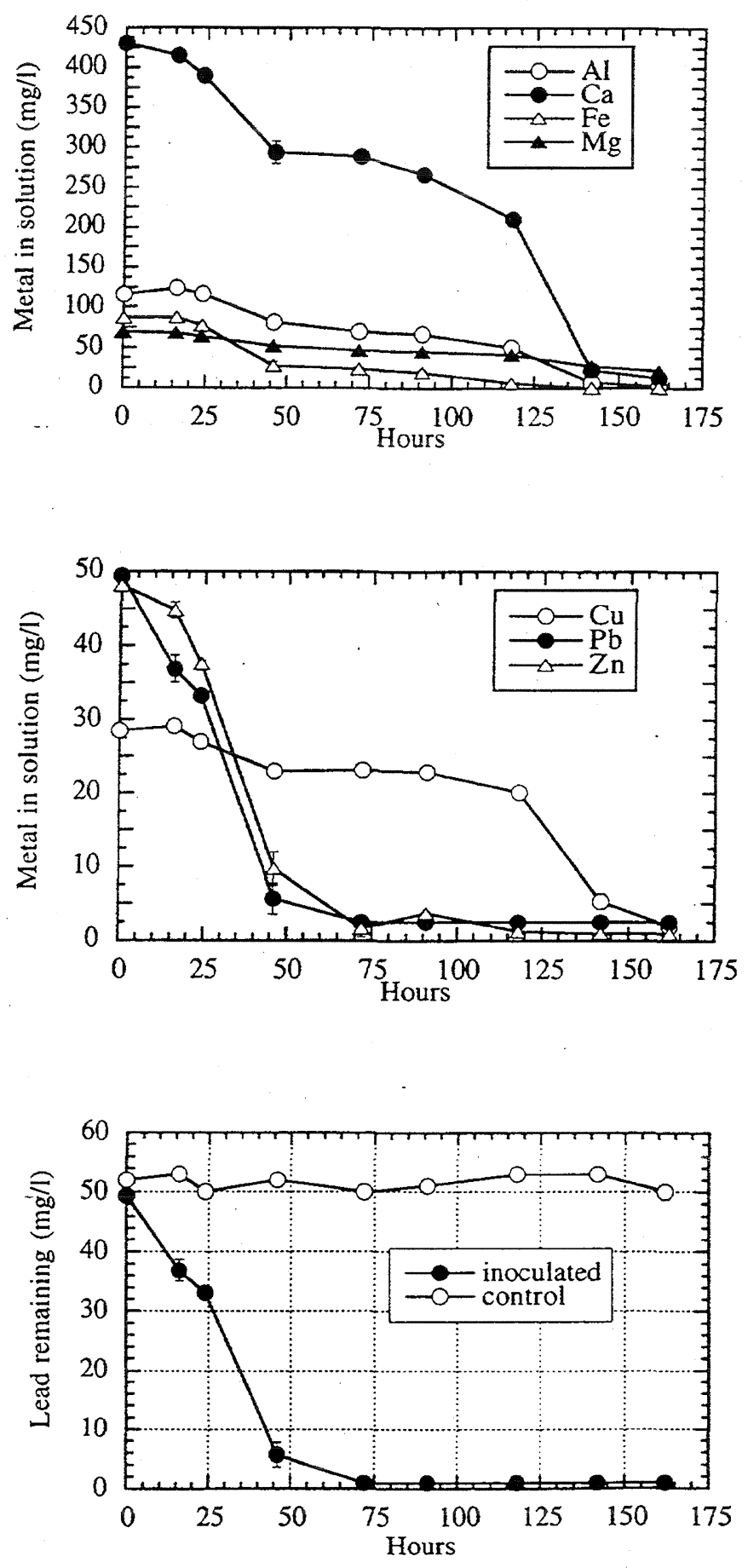

Figure 9. Metal removal from citric acid extract of bottom ash during biodegradation. 


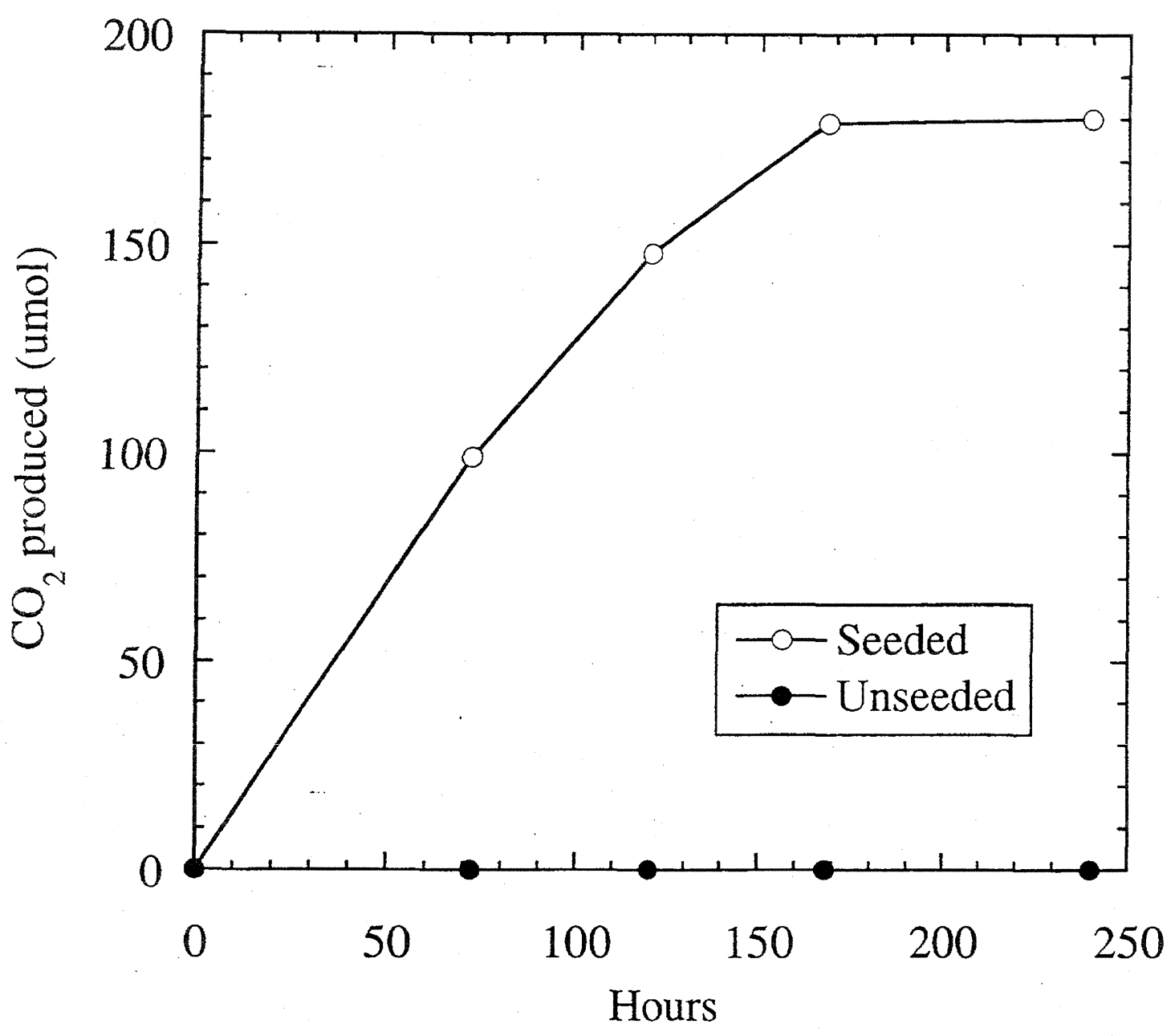

Figure 10. Carbon dioxide production in ash samples incubated after washing. 


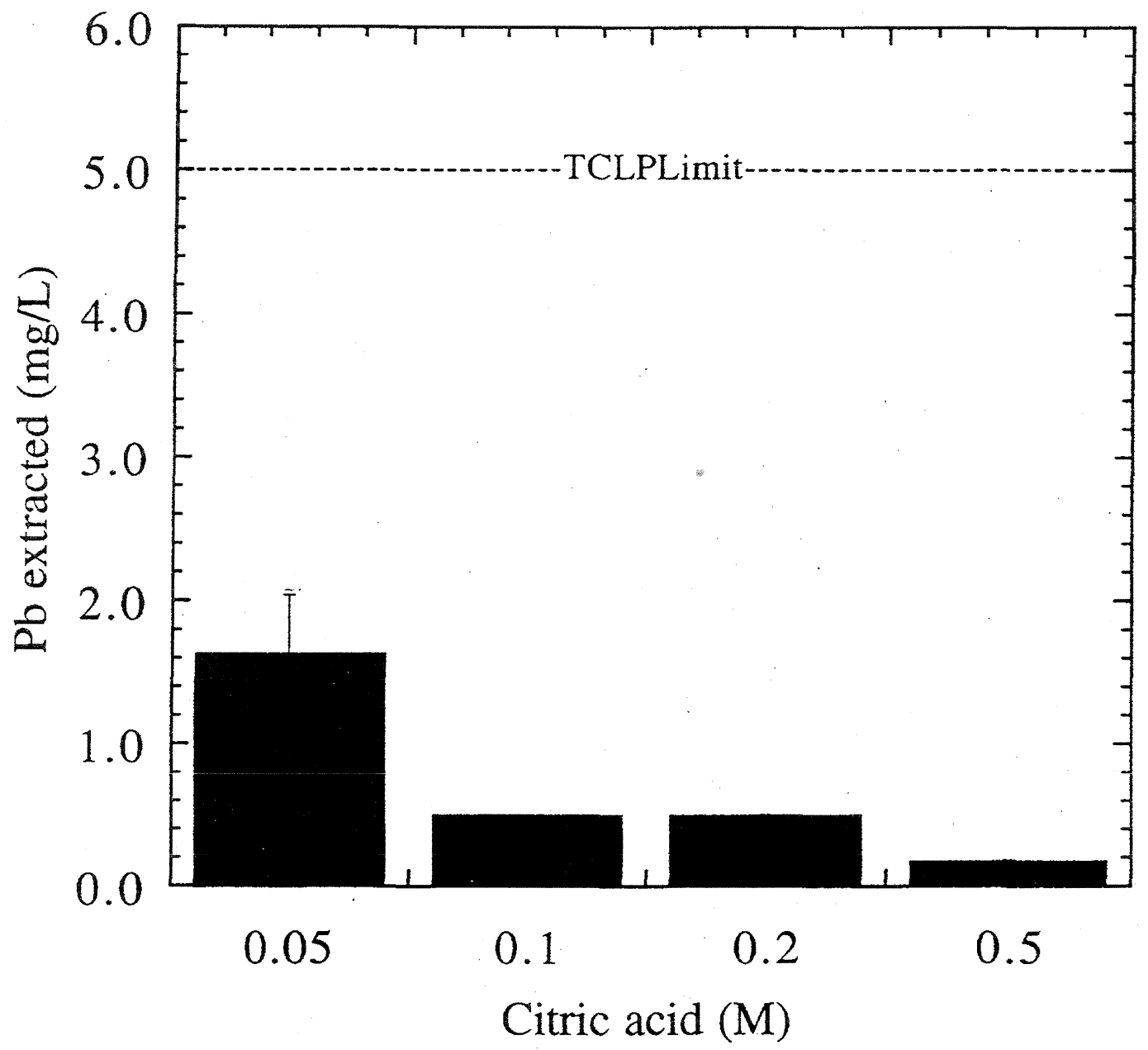

Figure 11. Effect of citric acid concentration on lead in TCLP extraction fluid 


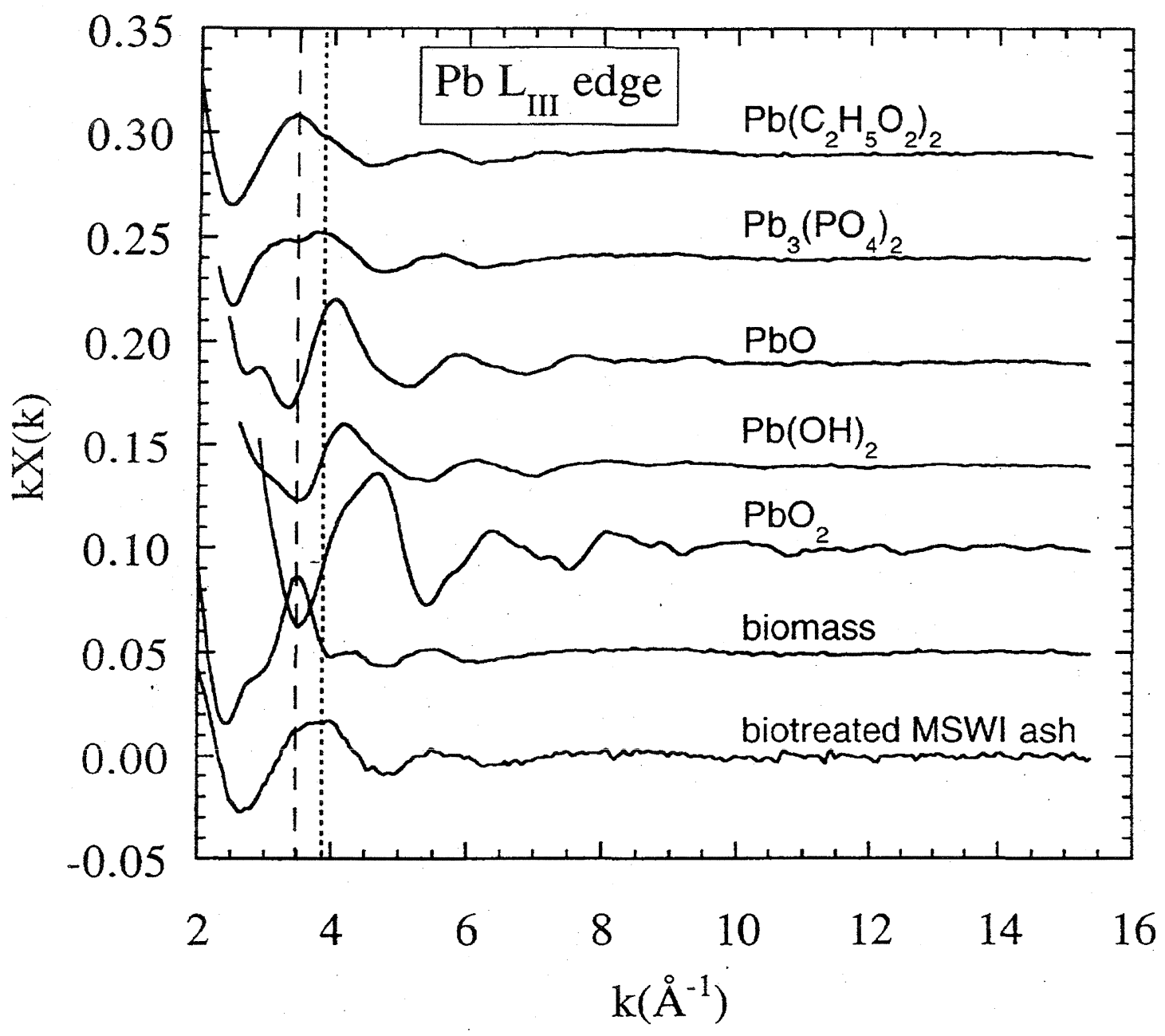

Figure 12. Speciation of $\mathrm{Pb}$ with bacterial biomass and biotreated MSWI ash 

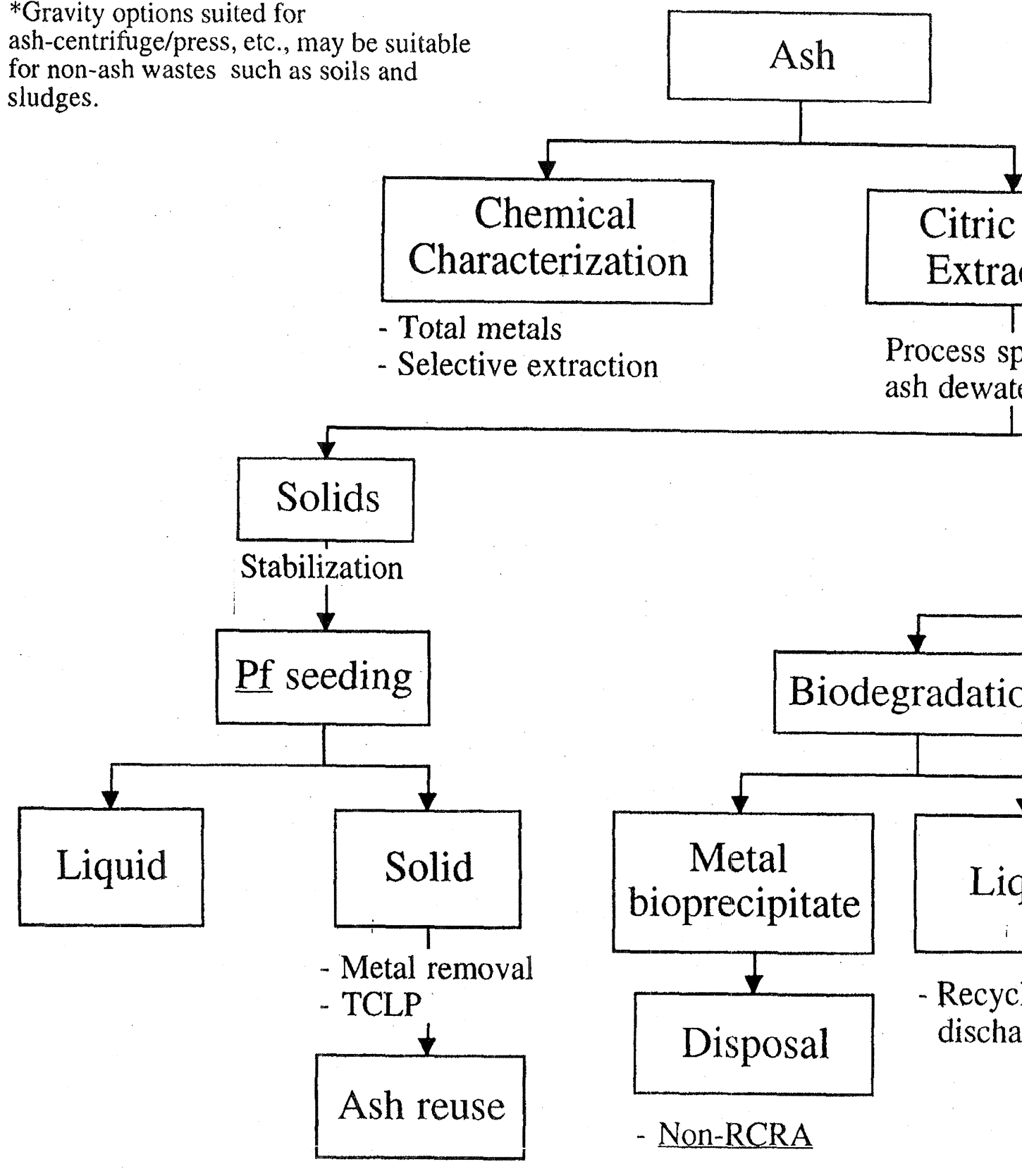